\title{
Reflections from an Adjunct: How the Scholarship of Teaching and Learning Empowers the Part-Time Instructor
}

\author{
Maria C. Durso, MA \\ Adjunct Instructor of English \\ Park University \\ “[The] scholarship of teaching ... requires a kind of 'going meta' in which faculty \\ frame and systematically investigate questions related to student learning." \\ Pat Hutchings and Lee S. Shulman, The Scholarship of Teaching: New \\ Elaborations, New Developments
}

In this reflective piece, an adjunct instructor narrates her experience with institutional efforts to encourage faculty to become better instructors through exposure to and engagement in the Scholarship of Teaching and Learning (SoTL). Institutions of higher education can find it difficult to draw faculty out of their instructional status quo. Of particular concern are part-time instructors who, typically less connected to the institution than full-time professors, may struggle to find the resources to improve instruction, even if such resources are desired. As a case in point, this piece demonstrates that early, consistent, persistent, quality exposure to SoTL, combined with individual commitment, does yield concrete improvement in teaching and learning.

The area of scholarship referred to as the Scholarship of Teaching and Learning (SoTL) seeks to result in "a public account of some or all of the full act of teaching, vision, design, enactment, outcomes" (Hutchings and Shulman, 1999, p. 13). This public account ensures that the scholarship will ultimately be "amenable to productive employment in future work by members of that same community" (p. 13). Although their part-time status regrettably tends to marginalize adjuncts in the professoriate, because SoTL is "public" and "amenable to productive use," exposure can serve to enhance adjuncts' roles in two ways: one, provide them with convenient and adaptive data and instruction useful for improving teaching outcomes, and two, encourage them to view the work they do in the classroom as a potential subject for empirical study. Unique in this regard, SoTL is accessible

I surmised that teaching scholarship could be beneficial in two ways: It encouraged me to consider ways to improve the learning experience in my classroom, and it honored my position in higher education as someone interested in research and scholarship. and relevant to the adjunct in ways that other scholarship is not. The public work of peers are resources, the classroom and students the lab. No grants, equipment, research library, or graduate assistants are necessary. What follows is a personal account of how institutional efforts consisting of strategic administrative and instructional exposure to SoTL served to empower me, a part-time instructor, in my pursuit of excellence in teaching and learning.

Upon completion of the hiring process for a historic liberal arts university, I was assigned an upper-level undergraduate course in business communication taught to working adults. The director at the satellite campus where I held this, my first post-secondary teaching assignment, handed me A Handbook for Adjunct/Parttime Faculty and Teachers of Adults by Donald Grieve (1996). Those familiar with this book know that it distills many valuable lessons that have been formalized in SoTL, such as the need for relevance and practical application in assignment design (p. 50), and the suggestion of case studies as a means toward this end (p. 37). The author asserts that there is a "greater emphasis on improved teaching" in today's college classroom, the result of an institutional response to the self-motivated adult learner (p. 1). Grieve implies, through reviewing current debates like that of andragogy versus pedagogy ( $p .12$ ) and including a collection of innovative 
classroom strategies (p. 63), that the institutions for which we teach are indeed "systematically investigating questions related to student learning" (Hutchings and Shulman, 1999, p. 13).

The director also periodically handed me photocopies from The Teaching Professor with the suggestion that they be added to my personal file of faculty development information. In the absence of an ongoing conversation with colleagues (I came and went at night after the office was closed, and only a few classes occupied the building), these materials kept me informed of a dialogue regarding successful practices for improving instruction and the systematic investigation that established them. This dialogue periodically and persistently reminded me of what Hutchings and Shulman call the "going meta" - that perpetual framing and investigating of questions in the pursuit of better teaching and learning - and thereby offered a more formal version of the heuristic work I did in my classroom (p. 13).

The needs of my students, aptly characterized by Grieve as self-directed (p. 50), and the need to improve my teaching, made evident by my campus director and institutional emails, converged once I felt more at home in my new position. My reading in The Teaching Professor indicated that preparing a class maximizing the students' wealth of experience in the professional world would provide a richer, more relevant learning experience than just doing exercises in the textbook. My students were, in their own words, "adult learners already in the business fields" who came to realize that they "deal with more business communications than [they] ever knew [they] did"; consequently, I encouraged them to create case studies based on a communication problem encountered in their own workplace. An article from The Teaching Professor, "Teachers Who Improved," encouraged this use of the students' experience to improve the learning environment. It indicated that establishing more active and practical learning helped to improve teaching performance. I added an involved mock-interview, requiring students to research beyond the text what interviewers in their chosen field would be looking for, to contact human resources departments and obtain interview formats and common interview questions, and ultimately to submit to an interview by the class. Another article showed why the development of such self-directed assignments in an upperdivision business-related class like mine was particularly important (Developing Students' Self-Directed Learning Skills, 2005, p. 5).

Additionally, I was in continual receipt of institutional publications via email pertaining to faculty development in the area of teaching and learning. The communication served to strengthen my connection to the institution and provide continuous exposure to SoTL. Two examples are illustrative: first, a frequently updated newsletter highlighting outstanding performance, often in the field of SoTL, by faculty, staff, and graduate students alike; second, periodic reminders, from both academic and developmental departments, of the resources available for faculty professional development related to teaching and learning.

In the former, I read about both tenured and adjunct faculty working in the field of SoTL, their accomplishments lauded and detailed. Full and assistant professors, as well as part-time instructors and lecturers of English and communications, were all represented and so served as both a resource and an inspiration for further learning. In the journals dedicated to SoTL, I was able to see, through reflective essays and case studies, the work others did in their classrooms. InSight and Change in particular gave me a clear sense of the framework involved for SoTL. Through these publications, I surmised that teaching scholarship could be beneficial in two ways: It encouraged me to consider ways to improve the learning experience in my classroom, and it honored my position in higher education as someone interested in research and scholarship. Additionally, these emails and photocopies modeled the way in which I would soon frame larger questions related to student learning.

Lack of initiative to reflect on, research, and reform teaching methods is present at all levels of the teaching hierarchy. As is often noted in SoTL literature, 
without engagement in SoTL even a tenured faculty member may feel that their teaching takes place in isolation. That isolation is greatly compounded in the parttimer, who does not even have the proverbial water cooler around which to casually discuss a problem, concern, or success story. I am sure that both full- and parttime faculty often feel there is not enough time to reflect on and re-tool our teaching as much we would like. In an investigation into what motivates a teacher to participate in professional development, Lee $\mathrm{S}$. and Judith $\mathrm{H}$. Shulman note that "a teacher can develop a new vision of teaching based on encountering role models, reading cases, viewing tapes, holding discussions with peers, reading theoretical accounts, etc" (2004, p. 261). Simply being exposed to the material does not mean that a faculty member will necessarily take action. However, as was true in my case, exposure and encouragement, initiated by administration, increased the likelihood that a faculty member like me would see any displeasure with the status quo as a problem that would have a solution somewhere in the ideas of SoTL. As if in anticipation of these moments from the start, my institution had prepared me to adopt this "new vision of teaching" when I was ready to do so. When I felt pressure to improve more than just assignment design, when I felt that the needs of my students necessitated a paradigm shift away from teacher-centered instruction, I had the tools to go about making a monumental change to a learner-centered classroom.

Three years later, at a different campus center belonging to the same university, I was reassigned Professional Writing in the Disciplines: Business Communication, but in an eight-week, one-night-per-week format. I had left the campus center where my director handed me copies of The Teaching Professor, but had that file of articles already tagged as useful by the institution. The course requires imparting a sizable amount of information and research about the best practices of business communication. I typically focused on an audience-centered, ethics-based approach to myriad communication forms, from memos to formal reports and presentations, relying heavily on those case studies to get students to practice techniques covered in the text. The time and location required a long drive in rush-hour traffic, followed by five hours of class, 5:30 until 10:30 PM, in a darkened campus center at a seemingly forgotten corner of a military base. My fear was that these circumstances would make ensuring that students felt provided with a satisfactory learning experience still more difficult. Traditional methods of skilland-drill and lecture-discussion, which can be effective in shorter doses, seemed particularly unappealing. It was clear to me that the "sage-on-the-stage" paradigm, which was encouraged by the required text and its accompanying wealth of power points, testing software, and videos, would be counterproductive as students ended a fourteen-hour day in the classroom. Exposure to the literature of SoTL offered the possibility of employing that "new vision of teaching" to address the concerns I had about these challenges.

While the time and place had some drawbacks, my students provided the raw material to make the course meaningful. They generally ranged in age from mid-twenties to mid-fifties and were either at the tail end of a long career in the military or in the middle of one in the defense industry. Because of this, they had the wisdom of experience, a wide and deep perspective to offer, and a wealth of real-world practical application from which to draw. In short, they had long resumes and regularly performed many of the communications tasks that the text introduced as though they were traditional twenty-year-old juniors in a residential college setting.

Grieve told me that I was to be a "facilitator of learning" (p. 57). His book suggested approaching my role not as the sole expert in the room, but as the means by which the information and skills the students needed could be attained. It occurred to me that this might entail something more involved than innovative assignment design. In hopes of gaining more insight into becoming a true facilitator, I reviewed my file of articles. Taken together, insights provided by Grieve and the articles in The Teaching Professor, along with the assignments inspired by them, made me realize that to truly become the "facilitator" of "active," "practical," and

InSight: A J ournal of Scholarly Teaching 
"self-directed" learning would require a paradigm shift away from teacher-centered instruction. I needed more detailed, practical instruction on how to do this, and it came from reading deeper into the Scholarship of Teaching and Learning.

The Teaching Professor is edited by Maryellen Weimer, so it was not long before I sought out and read her book, Learner-Centered Teaching: Five Key Changes to Practice (2002). A case study on the practices Weimer outlines by De De Wolfarth et al. in InSight, one of the journals sent to me by the institution, had already confirmed its value. In addition, I found Classroom Assessment Techniques by Angelo and Cross (1993), and Learner-Centered Assessment by Fenton and Watkins (2008). I credit the long reach of the institution's commitment to SoTL for directing me to these as texts of particular value and for encouraging the notion that successful pedagogy often requires exhaustive research of relevant scholarship.

I began to model my course on Weimer's "five key changes." Adopting the learner-centered classroom paradigm was immediately daunting. I believed that I knew what assignments needed to be done and which progression would work best. However, inspired by Weimer's "syllabus and learning log" (p. 203), I crafted an assignment menu to prepare my students to make many of these decisions for themselves, thereby providing that self-directed environment. This menu included many of the assignments that I typically used, but I followed advice found in Learner-Centered Assessment, which asserted that learning goals and outcomes should be clearly communicated (Fenton and Watkins, 2008, p. 6). To begin with, each menu included an estimated number of hours and a point value along with an outcomes rubric. Taking Weimer's instruction to heart, I transformed myself into a "master learner" (p. 87) and modeled many responses to assignments, some of which were added to what has become an "orientation packet" that we review on the first night.

I note that students assign themselves more work than I generally would have, keep to their due dates, and read the text more actively. On more than one occasion last term, the students kept class going past 10:30 PM on their own.

Following Weimer's practice of "developing a game plan" (p. 206), students choose which assignments they want to complete and the due dates. I use individual contracts to formalize these due dates. A set total point value has to be reached and the due dates adhered to. A contract template is used when students have decided which of the assignments they are going to do and when.

To ensure that students make "practical" choices about which assignments to pick, I start class with an involved self-reflection modeled on the background knowledge probe outlined by Angelo and Cross (p. 121). If Angelo and Cross felt that such an exercise could help me to make critical instructional decisions, I thought it might also help the students make critical learning decisions. Questions require them to consider their primary weaknesses: Are they oral or written? Where the need for improved application of communication skill is most urgently felt, is there an occasion requiring communication to achieve new employment? Professional development? Resolving communication issues at work? What does their preferred learning style require? Will they best achieve their goals with collaborative or individual efforts? With multimedia or text? They assess their own needs first, and apply their desire for practical application second. For example, if they are on the verge of changing careers, then they can choose employment communication for most of the assignment menu points, but the focus must be on the written communication if there is a need to strengthen those skills. Armed with this information, we adjourn until the following week, when their contracts are completed and signed.

Rather than use a regimented syllabus, I created a class calendar from these contracts. Weimer describes an instructor who adapts his syllabus to an early assessment of student needs (p. 40). My calendar is similarly customized. Starting with each student's due dates, I use it to outline when class time should be devoted to draft-conference groups and when I will provide lectures on theory and mini- 
lessons on skills. It allows me to design each class meeting to fully support and prepare them for their individual assignments. The variety of activities for each class (group discussion and group work on the chapters, draft conferences, minilessons by me, and presentations by, or interviews of, students) makes the time spent in the classroom industrious and driven by specific student needs.

As each class meeting embodies the changes I make, evidence of the power of the scholarship behind them comes in the form of both formal and informal student response. I note that students assign themselves more work than I generally would have, keep to their due dates, and read the text more actively. On more than one occasion last term, the students kept class going past 10:30 PM on their own. On institutional course assessments, students repeatedly report that the "value" they get from the course "exceed[s] expectations." It is heartening to read that the student impressions are that the course is one of the "better instructed" and that they feel "more challenged and interested." On classroom assessments at the end of the term, a few students vent furiously about how much they hate the process at the start. That the "tons of papers" and having to make "an individual schedule of what was to be due and when" is an unpleasant shock to the system. Weimer prepared me for this, and I see such responses as she does: grounded in the fear of added responsibility (p. 151). However, the evaluations are otherwise near-uniform praise of "what [I] was doing with the class" coupled with surprise at how much they come to value the "real world" application of the content and skills learned.

Having initiated a foray into SoTL as a researcher and experimenter of relevant scholarship on applicable pedagogy, I consider taking the next step of doing my own empirical research and collecting data that could provide more than anecdotal evidence of what I feel is successful teaching practice. I have begun a course portfolio in which my continuing work on this course is collected, documented, and subject to ongoing evaluation. My own greater comfort and confidence in the methods I employ in this course will steadily become grounded in quantifiable results, affording me the opportunity to produce scholarship of my own. I cannot imagine having considered embarking on such a project had I not been exposed to the SoTL done by my peers. Regardless, while I await the call from my new campus director offering another teaching appointment, I engage in the reflections you see here, continually reading, and plotting the ways in which I will address the challenges I face in my classroom. All the while, I am being reminded by those periodic emails and invitations for development that others are doing the same and more. It is my hope that it will and I will have thus fully engaged in what I see as an instrumental activity typically expected of only my full-time, tenuretrack peers.

\section{References}

Angelo, T. and Cross, P. (1993). Classroom assessment techniques: A handbook for college teachers. San Francisco: Jossey Bass.

Developing students' self-directed learning skills. (2009) The Teaching Professor 23.7(5-6), Web. 8 Mar. 2011.

Fenton, C. and Watkins, B. (2008). Learner-centered assessment: Real strategies for today's students. Phoenix: League for Innovation in the Community College.
Greive, D. A handbook for adjunct/part-time faculty and teachers of adults. Ohio: Info-Tech, Inc., 1996. Print.

Hutchings, P., \& Shulman, L. S. (1999) "he Scholarship of Teaching. Change 31.5(10), Academic Search Complete. EBSCO. Web. 10 Mar. 2011.

Shulman, L. S., \& Shulman, J. H., (Mar. 2004) How and what teachers learn: A shifting perspective. Journal of Curriculum Studies 36.2, 257-271. Web. 15 July 2010. 
Teachers Who Improved. (2009). The Teaching Professor 23.10(2), Web. 8 Mar. 2011.

Weimer, M. (2002). Learner-centered teaching: Five key changes to practice. San Francisco: Jossey-Bass.
Wolfarth, D., Sheras, D., Bennett, J.

L., Simon, B., Pimentel, J. H., \&

Gabel, L. E. (2008). Student

perceptions of learner-centered

teaching. InSight: A J ournal of

Scholarly Teaching 3, 67-74. Web. 10

Apr 2010.

Maria Durso has been teaching as an adjunct instructor for Park since 2004 at the Beaufort MCAS campus center. She received her Master's degree in English from Middlebury College. 